\title{
Feasibility Analysis of Honey Pineapple Farming in Belik Village, Belik District, Pemalang Regency
}

\author{
Nadzifatul Latifah ${ }^{1 *}$ and Pujastuti S. Dyah ${ }^{1}$
}

\author{
${ }^{1}$ Department of Agribusiness, Faculty of Agriculture, Universitas Muhammadiyah Yogyakarta 1 \\ *Corresponding author.Email: nadzifatul.l.fp16@mail.umy.ac.id
}

\begin{abstract}
Honey pineapple is annual plant whose plant origin comes from saplings. Honey pineapple plants can be harvested when the plant is 2 years old. This study aims to determine the feasibility of honey pineapple farming in Belik Village. The research method used in this study is a descriptive method that acts as a quantitative as its implementation technique. This research was conducted in Beluk Village, Belik District, Pemalang Regency, which was determine using purposive sampling method. This study involved 25 respondent farmers who are members of Sumber Nanas farmer group in Kerajan Halmet, Beluk Village, who were determined using the census sampling method. The result showed that the honey pineapple farming in Beluk Village, Belik District, Pemalang Regency was feasible in terms of : (1) Net present value with a bank interest rate of 7\%, the NPV value is IDR. 152.302.416 > 0, (2) The value of the Net Benefit Cost Ratio (Net B/C) is $4>1$, (3) The value of Internal Rate of Return (IRR) is 37,63\% greater than bank interest rates, which is 7\%, and (4) Calculation of Payback Period for honey pineapple farming can return investment in a period of 3,9 years.
\end{abstract}

Keywords: Farming, Feasibility, Honey Pineapple

\section{INTRODUCTION}

The agricultural sector is one of sectors that plays an important role for people of Indonesia because it contributes significantly to development of Indonesia economy and is a major factor in increasing country's income and foreign exchange. One of agricultural sub-sectors that occupies a strategic position in agricultural development is horticulture sub-sector. This is because horticultural sub-sector has contributed significantly to supporting national economy, both in provision of food, health and cosmetics products, trade, creation of gross domestic products and absorption of labor [1]. Horticultural crops spread almost throughout Indonesia, although the centers of several types of horticultural crops are in certain areas. This is due to suitability of climate, land and environmental conditions of community in developing certain types of horticultural crops. There are four types of plants horticulture sub-sector, namely vegetables, fruits, medicines (biopharmaceutical), ornamental plants (floriculture).

One of plants included in the horticultural sub-sector is fruit. Fruits are a type of plant that has potential to be developed in Indonesia. This is because Indonesia Has agroclimatic conditions that are suitable for development of various types of fruits. The diversity of fruit and advantages of agro-climate that Indonesia has is a good potential in facing international trade, considering that currently fruits have become commodities that traded in international market [2]. Several types of fruit in Indonesia are superior commodities and can compete in international market, namely pineapple, mangosteen, banana, mango, watermelon, and snake fruit. Pineapple production in Indonesia is experiencing fluctuating growth, meaning that from year to year fruit production experiences unstable fluctuations, namely in 2015 pineapple production in Indonesia reached 1.729.600 tons, then in 2016 pineapple production decreased as much as 33.459 tons and in 2017 pineapple production again increased to 1.795 .982 tons [3].

Pineapple is a horticultural commodity that has high economic value, not only domestic consumers consume it, but many foreign consumers also like and consume pineapple fruit that comes from Indonesia both in processed and fresh form. Most of Indonesia's pineapples are exported to United States, Netherlands and Spain in form of processed pineapples, namely canned pineapples with added sugar. In 2015, pineapple exports to United States reached 30,23\% of Indonesia's total pineapple exports, followed by Netherlands $(11,19 \%)$, and Spain $(10,59 \%)$. The cumulative pineapple exports of the three countries reached 52,55\% [4]. According to Ministry of Agriculture, pineapple production centers are almost scattered in various regions in Indonesia. Some pineapple production centers are Subang, Prabumulih, Kediri, Blitar, Kubu Raya, Mempawah Muaro Jambi, Lampung Tengah, Karimun, and one of them is Pemalang Regency [5]. Pemalang Regency consists of 14 districts, in which there are 4 districts that cultivate pineapples. One of centers of pineapple fruit production is Belik District, pineapple fruit production data for 2016, Belik District amounted to 28,615 
tons, while in 2017 pineapple fruit production decreased from 2016 amounting to 22.013,2 tons [6], [7].

The decline in pineapple fruit production in Belik District is due to fact that there are still many farmers who do not enough attention from government related to guidance and protection of pineapple plants, even though there are still many pineapple farmers in producing pineapple fruit that are not coordinated, so that pineapple production produced is not optimal and irregular [8]. In addition, the decline in pineapple production is also due to relatively extreme and unstable weather, so that many farmers have decreased pineapple productivity, while market demand for pineapple commodity is increasing. Cultivating honey pineapple in Belik subdistrict requires a lot of investment and operational costs, namely from land processing, planting, plant maintenance, to harvesting and other costs such as seeds, labor, fertilizers, pesticides, land rent, and equipment purchases. In year 0 to year 1 of planting, farmers have to pay for maintenance without obtaining revenue, while revenue will be obtained by farmers after plants are 1,5-2 years old, which is when plants produce fruit. In addition, in honey pineapple farming in second harvest and so on takes $6-7$ months to be harvested after first harvest. During that time, farmers need quite a lot od plant maintenance costs until fruit is ready for harvest.

The aims of research conducted in Beluk Village, Belik District, Pemalang Regency were to determine costs and benefits of honey pineapple farming and determine feasibility of honey pineapple farming in Beluk Village, Belik District, Pemalang Regency.

\section{RESEARCH METHOD}

The basic method used in research on the feasibility of honey pineapple farming in Belik District, Pemalang Regency is descriptive method. In this study, the descriptive method was used to determine the fact in the field, then analyzed and described a production input, cost incurred by farmers, profit, and feasibility of honey pineapple farming in Belik District.

This research is quantitative in nature, in discussion puts forward costs incurred by farmers during production process, inputs used in cultivation of honey pineapple, benefits received by farmers, and feasibility of honey pineapple farming in terms of Net Present Value (NPV), Net Benefit Cost Ratio (Net B/C), Internal Rate of Return (IRR), Payback Period. After that, it can be seen whether honey pineapple cultivation is feasible or not for cultivation.

\subsection{Sampling Technique}

\subsubsection{Identification Research Location}

The location of this research was conducted in Belik District, Pemalang Regency, to be precise, namely Beluk Village. The research location was chosen because from consideration of the result of previous observation, it was found that this location is a pineapple production center and produces the best production of pineapple fruit.

\subsubsection{Sample Farmer}

Sampling of farmers was taken from one of farmers group in Beluk Village with a non Probability sampling technique, namely purposive sampling. Based on information obtained, there are 11 farmer groups with a total of 1.526 farmers. Sampling was carried out on Sumber Nanas Farmer Group which is located in Kerajan Halmet, Beluk Village. Sampling was based on a recommendation from Belik District Agricultural Extension Officer because land area owned by Sumber Nanas Farmer Group was quite high, which was 77 hectare. In addition, with consideration based on head of farmer group that the farmers who are members of it are communicative and can provide information about honey pineapple cultivation properly.

The number of respondents was taken from members who are members of farmer group in Beluk Village with a nonprobability sampling technique, namely census sampling. Respondents were taken using census method, which is based on activeness of members in Sumber Nanas Farmer Group in Kerajan Halmet, Beluk Village, namely 25 farmers from a total of 167 members. Based on this, the number of samples to be used in study as respondents were 25 farmers who planted honey pineapple fruit and could represent plants aged 0 years to 8 years.

\subsection{Data Analysis Technique}

\subsubsection{Benefit}

Farming benefits (revenue) are all income ibtained from sale of products. To find out the benefits, use following this formula :

$$
\text { Benefit }=P x Q
$$

Information :

$$
\begin{array}{ll}
\text { Benefit } & =\text { Total revenue } \\
\mathrm{Q} & =\text { Output (Fruit) } \\
\mathrm{P} & =\text { Selling Price (IDR) }
\end{array}
$$

\subsubsection{Net Present Value}

Net Present Value (NPV) is present value of difference between benefits (revenue) and costs at a certain discount rate.

$$
\mathrm{NPV}=\sum_{i=0}^{n} \frac{\left(B_{t}-C_{t}\right)}{(1+i)}
$$

Information:

$$
\begin{array}{ll}
\mathrm{NPV} & =\text { Net Present Value } \\
\mathrm{Bt} & =\text { Benefits or revenue obtained every year } \\
\mathrm{Ct} & =\text { Costs obtained every year } \\
\mathrm{n} & =\text { Time (Year) } \\
\mathrm{i} & =\text { Bank interest rate or discount factor }(\%)
\end{array}
$$


Financial feasibility assessment based on NPV is NPV > 0 , meaning that honey pineapple farming is feasible to continue because benefits obtained are greater than costs incurred, NPV $<0$, meaning that honey pineapple farming is not feasible to continue because benefits obtained are smaller than costs incurred, and NPV $=0$, meaning that honey pineapple farming is difficult to continue because benefits are only enough to cover costs incurred.

\subsubsection{Internal Rate of Return}

Internal Rate of Return (IRR) is interest rate which illustrates that benefits that hve been presented in value and costs that have been presented in value indicate that NPV is equal to zero.

$$
I R R=i_{1}+\frac{N P V_{1}}{N P V_{1}-N P V_{2}}\left(i_{2}-i_{1}\right)
$$

Information :

$$
\begin{array}{ll}
\text { IRR } & =\text { Internal Rate of Return } \\
\mathrm{NPV}_{1} & =\text { Positive NPV } \\
\mathrm{NPV}_{2} & =\text { Negative NPV } \\
\mathrm{i}_{1} & =\text { Interest rate that result in NPV1 } \\
\mathrm{i} 2 & =\text { Interest rate that result in NPV2 }
\end{array}
$$

If the IRR value is greater than prevalling bank interest rate, then honey pineapple farming feasible to be cultivated. If the IRR value is less than prevalling bank interest rate, then honey pineapple farming is not feasible to cultivate.

\subsubsection{Net Benefit Cost Ratio}

Net Benefit-Cost Ratio (Net B/C) is ratio between net benefits that have been discounted positively and net benefit that have been discounted negatively.

$$
\text { Net } B / C=\frac{\sum_{t=1}^{n} \frac{B_{t}-C_{t}}{(1+i)^{t}}}{\sum_{t=1}^{n} \frac{C_{t}-B_{t}}{(1+i)^{t}}}
$$

Information :

$\mathrm{Bt}=$ Benefits obtained in year $\mathrm{t}$

$\mathrm{Ct}=$ Costs incurred in year $\mathrm{t}$

$\mathrm{n} \quad=$ Times to $\mathrm{n}$

$\mathrm{i}=$ Discount rate or interest rate

$\mathrm{t} \quad=$ Time

The assessment of value of Net $\mathrm{B} / \mathrm{C}$ Ratio is Net $\mathrm{B} / \mathrm{C}>1$, then honey pineapple farming is feasible to be cultivated or continued, Net $\mathrm{B} / \mathrm{C}<1$, then honey pineapple farming is not feasible to be cultivated or continued, and Net $\mathrm{B} / \mathrm{C}=1$, then honey pineapple farming is in break event point (BEP) position.

\subsubsection{Payback Period}

Payback Period is period of time required for return or tracking of investment costs that have been incurred in investing in a business.

$$
\text { Payback Period }=T_{p-1}+\frac{\sum_{i=1}^{n} I_{i}-\sum_{i=1}^{n} B_{i c p-1}}{B_{p}}
$$

Information :

$\mathrm{T}_{\mathrm{p}-1} \quad=$ The year before there was a payback period

Ii $\quad=$ The amount of discounted invesment

$\mathrm{B}_{\text {icp-1 }}=$ the amount of benefit that has been discounted before payback period

$\mathrm{Bp} \quad=$ The amount of benefit on payback period

If period of repayment of investment costs is faster, better and more feasible it is for honey pineapple farming to be continued. If investment cost repayment period is longer, the honey pineapple farming is not feasible to continue.

\section{RESULT AND DISCUSSION}

\subsection{Cost Honey Pineapple Farming}

Honey pineapple farming requires costs to meet the needs of the production process. Production costs incurred in form of investment costs and operational costs. Investment costs are costs incurred by farmers at beginning of cultivation activities and can also be incurred when farming is ongoing. Investment costs include cost of renting land, seeds, equipment, manure, labor for land preparation and planting, and labor for fertilizing manure. Meanwhile, operational costs are costs incurred by farmers on a regular basis and are calculated annually. Operational costs include ethrel, gloves, baskets, labor, taxes, and compost.

\subsubsection{Investment Cost}

The investment cost is taken from 3 farmers who still have plants in year 0 . The investment costs include cost of renting land, seeds, equipment, manure, labor for preparing land and planting, and labor for fertilizing manure. The following data regarding the investment costs required in honey pineapple farming can be seen in Table 1 . 
Table 1. Investment Cost for Honey Pineapple Farming in Beluk Village, Belik District, Pemalang Regency per 5,000 $\mathrm{m}^{2}$ (IDR)

\begin{tabular}{|c|c|c|c|c|c|c|c|c|c|c|}
\hline \multirow{2}{*}{ No } & \multirow{2}{*}{ Description } & \multicolumn{9}{|c|}{ Age of Plant - th Year } \\
\hline & & $\mathbf{0}$ & 1 & 2 & 3 & 4 & 5 & 6 & 7 & 8 \\
\hline 1 & Renting Land & 10.000 .000 & - & - & - & - & - & - & - & - \\
\hline 2 & Seeds & 20.000 .000 & - & - & - & - & - & - & - & - \\
\hline \multirow[t]{8}{*}{3} & \multicolumn{10}{|l|}{ Equipment : } \\
\hline & Hoe & 106.667 & - & - & - & - & - & 100.000 & - & \\
\hline & Sickle & 50.000 & - & 56.667 & 50.000 & 62.500 & 62.500 & 66.667 & 68.333 & 71.000 \\
\hline & Boots & 106.667 & - & 108.333 & 102.500 & 100.000 & 120.000 & 111.667 & 110.000 & 119.000 \\
\hline & Flit Sprayer & 209.000 & - & 207.000 & - & 200.000 & - & 208.000 & - & 206.400 \\
\hline & Crowbar & 107.700 & - & - & - & - & - & - & - & 106.400 \\
\hline & Machete & 200.000 & - & - & - & - & - & 50.000 & - & - \\
\hline & Total Equipment Costs & 780.034 & - & 372.000 & 152.500 & 362.500 & 182.500 & 536.334 & 178.333 & 502.800 \\
\hline 4 & Manure & 2.000 .000 & - & - & - & - & - & - & - & - \\
\hline 5 & $\begin{array}{l}\text { Labor for Preparing Land and } \\
\text { Planting }\end{array}$ & 14.833 .333 & - & - & - & - & - & - & - & - \\
\hline 6 & Labor for Fertilizing Manure & 1.000 .000 & - & - & - & - & - & - & - & - \\
\hline & Total & 48.613.367 & - & 372.000 & 152.500 & 362.500 & 182.500 & 536.334 & 178.333 & 502.800 \\
\hline
\end{tabular}

\subsubsection{Renting Land}

The land used for honey pineapple farming is land that is owned by farmers. Cost of renting land is a cost that is actually incurred by farmer, and is a one-time expense at the beginning of investment or preparation year. The cost of renting a land is issued once at the beginning of investment with a land area of IDR. 10,000,000, - during the investment period of 8 years (in Table 1).

\subsubsection{Seeds}

Cost of purchasing honey pineapple seeds is incurred once at the beginning of planting. It can be seen that average purchase of honey pineapple seeds with a land area of 5,000 $\mathrm{m}^{2}$ is IDR. 20,000,000, - with a number of seeds of 40,000 plants and a price per seed of IDR. 500, - (in Table 1).

\subsubsection{Equipment}

In Table 1, it is known that investment costs incurred for equipment each year are not same, because each equipment has a different economic age. The largest equipment investment costs were incurred in year 0 , because all equipment was purchased in that year with a total equipment cost of IDR. 780,034, -.

\subsubsection{Manure}

The use of manure by honey pineapple farmers in Beluk Village with a land area per $5,000 \mathrm{~m}^{2}$ reaches $8,000 \mathrm{~kg}$ at a price of IDR. $250,-/ \mathrm{kg}$ and the average cost of processing fertilizer is IDR 2,000,000 for 8 years (in Table 1).

\subsubsection{Labor for Land Preparation and Planting}

In Table 1, it is known that average cost for labor for land preparation and planting with a land area of $5,000 \mathrm{~m}^{2}$ is IDR. $14,833,333$, - or rounded to IDR. $14,800,000$ over an investment period of 8 years.

\subsubsection{Labor for Fertilizer Manure}

In Table 20, it is known that average cost incurred by farmers for manure fertilizing labor with a land area per 5,000 $\mathrm{m}^{2}$ is IDR. 1,000,000, - during investment period of 8 years.

\subsubsection{Total Invesment Cost}

The largest total investment cost for honey pineapple farming in Beluk Village in year 0 is IDR. 48,613,367, - (in Table 20). This cost is an illustration of value needed by farmers in starting a honey pineapple farming business with a land area of $5,000 \mathrm{~m}^{2}$ for an investment period of 8 years.

\subsubsection{Operational Cost}

Operational costs are costs incurred during process of farming activities and are outside of investment costs. Operational costs include ethrel, equipment (gloves and baskets), labor, taxes, and compost. The use of operational costs is calculated from year 1 to year 8 . The components of operational costs for honey pineapple farming in Beluk Village are as follows: 
Table 2. Operational Costs of Honey Pineapple Farming in Beluk Village, Belik District, Pemalang Regency per 5,000 $\mathrm{m}^{2}$ (IDR)

\begin{tabular}{|c|c|c|c|c|c|c|c|}
\hline \multirow{2}{*}{$\begin{array}{c}\text { Age of } \\
\text { Plant - } \\
\text { Year }\end{array}$} & \multirow[b]{2}{*}{ Ethrel } & \multicolumn{2}{|c|}{ Equipment Cost } & \multirow[b]{2}{*}{ Labors } & \multirow[b]{2}{*}{ Taxes } & \multirow[b]{2}{*}{ Compost } & \multirow[b]{2}{*}{ Total } \\
\hline & & Gloves & Baskets & & & & \\
\hline 0 & - & - & - & - & - & - & - \\
\hline 1 & - & 3.500 & 108.000 & 2.133 .333 & 75.000 & - & 2.319 .833 \\
\hline 2 & 20.000 & 4.000 & 108.000 & 4.395 .000 & 75.000 & 1.746 .877 & 6.348.877 \\
\hline 3 & 40.000 & 4.500 & 118.000 & 9.800 .000 & 75.000 & 3.265 .192 & 13.302.692 \\
\hline 4 & 40.000 & 5.000 & 100.000 & 10.880 .000 & 75.000 & 3.051 .581 & 14.151 .581 \\
\hline 5 & 40.000 & 4.300 & 109.000 & 6.032 .500 & 75.000 & 2.851 .945 & 9.112 .745 \\
\hline 6 & 40.000 & 3.800 & 113.000 & 4.093 .333 & 75.000 & 2.665 .369 & 6.990 .502 \\
\hline 7 & 40.000 & 5.000 & 107.000 & 3.521 .667 & 75.000 & 4.000 .000 & 7.748.667 \\
\hline 8 & 40.000 & 4.000 & 107.000 & 7.110 .000 & 75.000 & 4.000 .000 & 11.336 .000 \\
\hline
\end{tabular}

\subsubsection{Ethrel}

Based on Table 2, it is known that the total cost incurred by farmers for purchasing ethrel with a land area per $5,000 \mathrm{~m}^{2}$ is IDR. 20,000, - in the 2nd year and 3rd to 8th year of IDR. $40,000,-$

\subsubsection{Equipment}

Based on Table 2, it is known that the largest total cost incurred for equipment is IDR. 122,500 , - in the 3 rd year.

\subsubsection{Labor}

Based on Table 2, it is known that the total labor cost of maintaining plants in honey pineapple farming in Beluk Village with the largest land area per $5,000 \mathrm{~m}^{2}$ in the fourth year is IDR. 10,880,000, -

\subsubsection{Taxes}

In Table 2, it is known that the tax costs incurred by farmers with a land area per $5,000 \mathrm{~m}^{2}$ is IDR. 75,000, - per year. The tax expense is incurred annually from year 1 to year 8.

\subsubsection{Compost}

Based on Table 25, it is known that the largest total cost of purchasing compost with a land area per $5,000 \mathrm{~m}^{2}$ is IDR. $4,000,000,-$ incurred in the 7 th and 8 th years.

\subsubsection{Total Operational Cost}

Based on Table 2, it is known that the largest total operational cost, namely for plants aged 4, is IDR. $15,100,000$, -. This cost is an illustration of the value required in running honey pineapple farming with a land area of 5,000 $\mathrm{m}^{2}$ for a period of 1 year.

\subsubsection{Total Cost}

Total cost of honey pineapple farming in Beluk Village is sum of investment costs and operational costs. The total costs incurred will affect benefits and feasibility of honey pineapple farming. The average total costs incurred in honey pineapple farming are as follows:

Based on Table 3, it is known that the largest total cost of honey pineapple farming in year 0 is IDR. 48,613,367, which includes investment costs and operational costs.

\subsection{Benefit}

Benefits of honey pineapple farming in Beluk Village are obtained from multiplication of amount of honey pineapple production and price per grain. Benefits start to be obtained when honey pineapple plant begins to bear fruit or produces fruit. Honey pineapple plant has started to be harvested at age of plant 2 years.

Table 3. Benefits of Honey Pineapple Farming in Beluk Village, Belik District, Pemalang Regency per 5,000 m2

\begin{tabular}{|c|r|r|r|}
\hline \multirow{2}{*}{$\begin{array}{c}\text { Year } \\
\text { to }-\end{array}$} & $\begin{array}{c}\text { Total } \\
\text { (Grain) }\end{array}$ & $\begin{array}{c}\text { Benefit } \\
\text { (IDR/Grain) }\end{array}$ & Value (IDR) \\
\hline 0 & - & - & - \\
\hline 1 & - & - & - \\
\hline 2 & 15.000 & 1.000 & 15.000 .000 \\
\hline 3 & 30.000 & 1.000 & 30.000 .000 \\
\hline 4 & 30.000 & 1.300 & 39.000 .000 \\
\hline 5 & 40.000 & 1.500 & 60.000 .000 \\
\hline 6 & 40.000 & 1.800 & 72.000 .000 \\
\hline 7 & 40.000 & 2.000 & 80.000 .000 \\
\hline 8 & 40.000 & 2.000 & 80.000 .000 \\
\hline
\end{tabular}

In Table 3, it is known that the greatest benefit generated from farming honey pineapple in Beluk Village with a land area of $5,000 \mathrm{~m} 2$ is IDR. $80,000,000$, - in 7 th and 8 th years, 
with total production in 7 th and 8th years as many as 40,000 items.

\subsection{Feasibility of Honey Pineapple Farming}

Honey pineapple is an annual plant that has an economic age and a long harvest period if it is properly maintained. To find out the feasibility of farming, several approaches are needed based on the feasibility criteria. Each feasibility criterion has different calculations and objectives. The honey pineapple farming period is a period of years. The feasibility criteria for honey pineapple farming include Net Present

Table 4. Net Present Value of Honey Pineapple Farming in Beluk Village, Belik District, Pemalang Regency per 5,000 $\mathrm{m}^{2}$

\begin{tabular}{c|c|c|c|c|c|c|c|}
\hline Year & $\begin{array}{c}\text { Total } \\
\text { Cost }\end{array}$ & Benefit & Benefit - Total Cost & $\begin{array}{c}\text { DF } \\
\mathbf{( 7 \% )}\end{array}$ & PV.C & PV.B & NPV \\
\hline 0 & 48.613 .367 & - & $(48.613 .367)$ & 1,00 & 48.613 .367 & - & $(48.613 .367)$ \\
\hline 1 & 2.319 .833 & - & $(2.319 .833)$ & 0,93 & 2.168 .069 & - & $(2.168 .069)$ \\
\hline 2 & 6.720 .877 & 15.000 .000 & 8.279 .123 & 0,87 & 5.870 .275 & 13.101 .581 & 7.231 .306 \\
\hline 3 & 13.455 .192 & 30.000 .000 & 16.544 .808 & 0,82 & 10.983 .444 & 24.488 .936 & 13.505 .492 \\
\hline 4 & 14.514 .081 & 39.000 .000 & 24.485 .919 & 0,76 & 11.072 .723 & 29.752 .913 & 18.680 .190 \\
\hline 5 & 9.295 .245 & 60.000 .000 & 50.704 .755 & 0,71 & 6.627 .381 & 42.779 .171 & 36.151 .790 \\
\hline 6 & 7.526 .836 & 72.000 .000 & 64.473 .164 & 0,67 & 5.015 .448 & 47.976 .640 & 42.961 .192 \\
\hline 7 & 7.927 .000 & 80.000 .000 & 72.073 .000 & 0,62 & 4.936 .537 & 49.819 .979 & 44.883 .442 \\
\hline 8 & 11.838 .800 & 80.000 .000 & 68.161 .200 & 0,58 & 6.890 .289 & 46.560 .728 & 39.670 .439 \\
\hline & \multicolumn{7}{|c|}{ Total } \\
\hline
\end{tabular}

Based on Table 4, it is known that the NPV value with an interest rate of $7 \%$ is IDR. 152,302,416, -. The NPV value shows net benefits obtained by honey pineapple farming in Beluk Village during farming life with an interest rate of $7 \%$. Thus, the calculation of NPV value of honey pineapple farming in Beluk Village, Belik District, Pemalang Regency is feasible to run. This is because the resulting NPV value is greater than 0 as the limit of the NPV feasibility criteria.

\subsubsection{Net Benefit Cost Ratio}

Net Benefit Cost Ratio (Net B/C) is a measurement tool used to see amount of benefits obtained from each unit incurred by honey pineapple farming. Net $\mathrm{B} / \mathrm{C}$ is obtained from the comparison between the total positive NPV value and negative NPV value of a project in order to obtain net benefits in present. Net $\mathrm{B} / \mathrm{C}$ calculation is shown in Table 5 .

Table 5. Net Benefit Cost Ratio Value of Honey Pineapple Farming in Beluk Village, Belik District, Pemalang Regency per $5,000 \mathrm{~m}^{2}$

\begin{tabular}{|l|r|l|}
\hline Description & \multicolumn{1}{|c|}{ NPV } & Value \\
\hline NPV (-) & $(48.613 .367)$ & $(50.781 .435)$ \\
\hline & $(2.168 .069)$ & \\
\hline NPV (+) & 7.231 .306 & 203.083 .851 \\
\hline & 13.505 .492 & \\
\hline & 18.680 .190 & \\
\hline & 36.151 .790 & \\
\hline & 42.961 .192 & \\
\hline & 44.883 .442 & \\
\hline & 39.670 .439 & \\
\hline & & \\
\hline \multicolumn{2}{|c|}{ Net B/C } \\
\hline
\end{tabular}

Value (NPV), Net Benefit Cost Ratio (Net B / C), Internal Rate of Return (IRR), and Payback Period.

\subsubsection{Net Present Value}

Net Present Value (NPV) is net present value which is the difference between benefits and costs by taking into account current bank interest rate as a discount factor (DF). The discount rate used is Bank Rakyat Indonesia interest rate of $7 \%$. The following are results of the NPV analysis of honey pineapple farming seen in Table 5 . 
Table 6. Internal Rate of Return Value of Honey Pineapple Farming in Beluk Village, Belik District, Pemalang Regency per $5,000 \mathrm{~m}^{2}$

\begin{tabular}{|c|r|r|r|r|r|r|}
\hline Year & Benefit - Total Cost & DF (37\%) & \multicolumn{1}{c|}{ NPV1 } & DF (38\%) & \multicolumn{1}{c|}{ NPV2 } \\
\hline 0 & $(48.613 .367)$ & 1,00 & $(48.613 .367)$ & 1,00 & $(48.613 .367)$ \\
\hline 1 & $(2.319 .833)$ & 0,73 & $(1.693 .309)$ & 0,72 & $(1.681 .039)$ \\
\hline 2 & 8.279 .123 & 0,53 & 4.411 .062 & 0,53 & 4.347 .365 \\
\hline 3 & 16.544 .808 & 0,39 & 6.434 .281 & 0,38 & 6.295 .417 \\
\hline 4 & 24.485 .919 & 0,28 & 6.950 .790 & 0,28 & 6.751 .497 \\
\hline 5 & 50.704 .755 & 0,21 & 10.506 .205 & 0,20 & 10.131 .022 \\
\hline 6 & 64.473 .164 & 0,15 & 9.751 .144 & 0,14 & 9.334 .788 \\
\hline 7 & 72.073 .000 & 0,11 & 7.956 .620 & 0,10 & 7.561 .692 \\
\hline 8 & 68.161 .200 & 0,08 & 5.492 .533 & 0,08 & 5.182 .085 & $\mathbf{\Xi}$ \\
\hline & \multicolumn{2}{c}{ Total } & $\mathbf{1 . 1 9 5 . 9 6 0}$ & & $\mathbf{( 6 9 0 . 5 3 9 )}$ & $\mathbf{3 7 , 6 3}$
\end{tabular}

Based on Table 6 , it is known that the IRR value on honey pineapple farming in Beluk Village, Belik District, Pemalang Regency is $37.63 \%$. This value shows that honey pineapple farming in Beluk Village generates a profit of $37.63 \%$ of the capital issued, so that honey pineapple farming has the ability to pay back the capital or loan interest that has been used.

\subsubsection{Payback Period}

Payback Period is a period of return on investment which is indicated by the occurrence of cumulative cash in flows equal to the present value of investment. Payback period analysis is used in a feasibility study to show how long it takes for a farm to return investment. The payback period value calculated at an interest rate of $7 \%$ is presented in Table 7.

Table 7. Payback Period Value of Honey Pineapple Farming in Beluk Village, Belik District, Pemalang Regency per $5,000 \mathrm{~m}^{2}$

\begin{tabular}{|c|c|c|c|c|c|c|}
\hline Year & Invesment Costs & Benefit & DF (7\%) & PVIC & PVB & \multirow{10}{*}{ 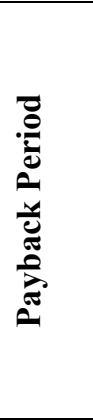 } \\
\hline 0 & 48.613 .367 & - & 1,00 & 48.613 .367 & - & \\
\hline 1 & - & - & 0,93 & - & - & \\
\hline 2 & 372.000 & 15.000 .000 & 0,87 & 324.919 & 13.101 .581 & \\
\hline 3 & 152.500 & 30.000 .000 & 0,82 & 124.485 & 24.488 .936 & \\
\hline 4 & 362.500 & 39.000 .000 & 0,76 & 276.550 & 29.752 .913 & \\
\hline 5 & 182.500 & 60.000 .000 & 0,71 & 130.120 & 42.779 .171 & \\
\hline 6 & 536.333 & 72.000 .000 & 0,67 & 357.382 & 47.976 .640 & \\
\hline 7 & 178.333 & 80.000 .000 & 0,62 & 111.057 & 49.819 .979 & \\
\hline 8 & 502.800 & 80.000 .000 & 0,58 & 292.634 & 46.560 .728 & \\
\hline Total & & & 6,97 & 50.230 .514 & 254.479 .949 & 3,9 \\
\hline
\end{tabular}

Based on Table 7, it is known that the payback period for honey pineapple farming in Beluk Village, Belik District, Pemalang Regency is 3.9 years. This shows that honey pineapple farming is feasible because it provides a quick return on investment.

\section{CONCLUSION}

Based on result of research on honey pineapple farming in Beluk Village, Belik District, Pemalang Regency, with a converted land ares of $5.000 \mathrm{~m}^{2}$, it can be concluded that honey pineapple farming is feasible in terms of :

a. Net Present Value (NPV) with a bank interest rate of 7\%, NPV value is IDR. 152,302,416, - greater than 0 (zero).

b. Net Benefit Cost Ratio (Net B / C) of 4 is greater than 1, indicating that profits obtained when plants have produced can cover losses when plants have not produced.

c. Internal Rate of Return (IRR) is $37.63 \%$ greater than discount rate (prevailing bank interest rate), which is $7 \%$.

d. Payback Period calculation for honey pineapple farming can return investment cost in a period of 3.9 years.

\section{REFERENCES}

[1] Badan Pusat Statistik Jawa Tengah, Provinsi Jawa Tengah Dalam Angka 2018. Semarang: Badan Pusat Statistik Provinsi Jawa Tengah, 2018.

[2] A. K. Wardani, "Analisis Usahatani Nanas Pada Kelompok Tani Makmur Desa Astomulyo Kecamatan Punggur Lampung Tengah,” Institut Pertanian Bogor, 2012. 
[3] Kementrian Pertanian, Statistik Pertanian (Agricultural Statistic) 2018. Jakarta: Pusat Data dan Sistem Informasi Pertanian Kementrian Pertanian Republik Indonesia, 2018.

[4] P. D. dan S. I. P. S. J. K. Pertanian, Outlook Nenas. Jakarta: Pusat Data dan Sistem Informasi Pertanian Sekretariat Jendral Kementrian Pertanian, 2016.

[5] A. Nasrulhak, "Ekspor Nanas 2018 Capai 11 Robu Ton, Dari Saudi Hingga Korea," www.detik.com, 2018. [Online]. Available: https://m.detik.com/finance/beritaekonomi-bisnis/d-4335725/ekspor-nanas-2018-capai11-ribu-ton-dari-saudi-hingga-korea. [Accessed: 27Oct-2019].
[6] Badan Pusat Statistik Kabupaten Pemalang, Pemalang Dalam Angka 2017. Pemalang: Badan Pusat Statistik Kabupaten Pemalang, 2017.

[7] Badan Pusat Statistik Kabupaten Pemalang, Pemalang Dalam Angka 2018. Pemalang: Badan Pusat Statistik Kabupaten Pemalang, 2018.

[8] Monitor.co.id, "Harapan Petani Nanas di Pemalang Terkait Program Desa Vokasi," www.monitor.co.id, 2017. [Online]. Available: https://monitor.co.id/2017/11/20/harapan-petani-nanasdi-pemalang-terkait-program-desa-vokasi/. [Accessed: 28-Oct-2019]. 